\title{
Aspectos etiológicos da mordida aberta anterior e suas implicações nas funções orofaciais***
}

\author{
Etiological aspects of anterior open bite and its implications to \\ the oral functions
}

Cristina Tostes Vieira Maciel* (cristostesmaciel@bol.com.br)

Isabel Cristina Gonçalves Leite**

*Fonoaudióloga. Especializanda em Motricidade Oral pelo Centro Especializado em Fonoaudiologia Clínica (CEFAC) do Rio de Janeiro. Fonoaudióloga Clínica no Centro de Reabilitação de Odontologia de Juiz de Fora.

**Cirurgiã-Dentista. Doutora em Saúde Pública pela Fundação Oswaldo Cruz do Rio de Janeiro. Professora Titular da Universidade Presidente Antônio Carlos, Campus VI.

***Trabalho Realizado em Fernão Dias Paes, Juiz de Fora (MG). Parte da Monografia de Conclusão do Curso de Fonoaudiologia da Universidade Presidente Antônio Carlos.

Artigo de Pesquisa

Artigo Submetido a Avaliação por Pares

Conflito de Interesse: não

Recebido em 17.11.2004. Revisado em 18.01.2005; 17.06.2005; 15.08.2005; 3.10.2005. Aceito para Publicação em 10.10.2005.

\begin{abstract}
Background: open bite is a complex anomaly that has a difficult treatment. Frequently, unsatisfactory results and relapse of orthodontic treatment are observed. Aim: to associate orofacial malfunction and deleterious oral habits to anterior open bite. To congregate evidences for the better understanding of the etiology and of the development of anterior open bite and its potential association to myofunctional disorders. Method: an exploratory study, to obtain relative risk measurements associating clinical characteristics, sucking habits and myofunctional alterations in 130 scholars. This study was developed in two stages: the first was based on a questionnaire about the child's oral habits which was answered by the parents, and the second involved odontologic and speech-language evaluations. Results: in this sample, the most prevalent occlusion disorder was anterior open bite, which was associated to vertical facial growth (relative risk (RR) 3.12; confidence internal (CI) 1.20 - 9.90) and to Angle's Class II malocclusion (p-value $=0.01)$. An association was also observed for anterior open bite and lingual interference (RR 2.44; CI 1.13-5.27). The same was not observed for speech disorders (RR 0.80; CI 0.20-2.30). Conclusion: a correlation exists between the etiology of anterior open bite, deleterious oral habits, and a few orofacial malfunctions. An association between the history of deleterious habits and the occurrence of lingual interposition during swallowing, as well as with speech disorders was identified. These findings emphasize the necessary interaction between orthodontists and speech-language pathologist during the treatment of patients. The rehabilitation role of speech-language therapy stands out, through the oral myofunctional therapy, emphasizing the positioning of the tongue during swallowing, speech and when in habitual position.
\end{abstract}

Key Words: Open Bite; Dentistry; Speech-Language Pathology; Sucking Behavior.

\section{Resumo}

Tema: a mordida aberta é uma anomalia complexa e de difícil tratamento. Comumente são vistos resultados insatisfatórios e a recidiva de tratamento na clínica ortodôntica. Objetivo: associar disfunções orofaciais e hábitos orais deletérios à mordida aberta anterior, reunindo evidências que colaborem para o melhor entendimento da etiologia e do desenvolvimento da mordida aberta anterior e sua potencial associação a alterações miofuncionais na amostra estudada. Método: estudo exploratório, derivando medidas de associação entre as condições clínicas, hábitos de sucção e alterações miofuncionais de 130 escolares. Estudo realizado em duas etapas, sendo a primeira a devolução de um questionário remetido ao responsável sobre hábitos bucais e a segunda caracterizada pelo exame clínico odontológico e fonoaudiológico dos menores autorizados. Resultados: na amostra, o padrão de má-oclusão mais prevalente foi a mordida aberta anterior, que se associou com o padrão de crescimento vertical da face (risco relativo 3,12 ; intervalo de confiança 1,20 - 9,90) e com a classe II de Angle (p-valor =0,01). Associação entre a mordida aberta anterior e interposição lingual (RR 2,44; IC 1,13 - 5,27). O mesmo não foi verificado para as deficiências na fonoarticulação ( $R R=0,80$; IC 0,20 - 2,30). Conclusão: há uma correlação etiológica da mordida aberta anterior com hábitos orais deletérios e algumas alterações das funções orofaciais. Foi identificada associação entre o histórico de hábitos parafuncionais e a ocorrência de interposição lingual em deglutição e a deficiência fonoarticulatória. É notória a necessidade da interação entre ortodontistas e fonoaudiólogos no atendimento integral do paciente portador de mordida aberta. Ressalta-se o papel reabilitador da terapia fonoaudiológica, através da terapia miofuncional oral, enfatizando o posicionamento da língua durante a deglutição, a fala e quando em posição habitual.

Palavras-Chave: Mordida Aberta; Odontologia; Fonoaudiologia; Comportamento de Sucção. 


\section{Introduction}

The open bite in a complex anomaly of distinct characteristics and of difficult treatment, once the vertical dimensions control in a malocclusion requires experience from the odontologist and cooperation of the patient, besides the involvement of other areas such as the speech-language pathology (Cirelli et al., 2001; Monguilhott et al., 2003).

The anomaly is almost always related to some habit through which the infra-occluded teeth were mechanically blocked to complete their eruption. This will consequently involve a varying number of teeth according to the influence of the causal agent (Siqueira et al., 2002).

This issue is of great interest since the unsatisfactory results and the recidive of the treatment are common in the orthodontic clinic. If, on one hand the stability of a positive result orthodontically obtained depends on the functional normalization, on the other hand the persistence and duration of deleterious habits may lead to the installation of malformations (Siqueira et al., 2002).

Only the harmful habits of pressure and the functional aberration could be controlled, through prophylactic or preventive measures of malocclusions. Even though, certain problems of this area escape from the knowledge and the practice of the dentist-surgeon, being target of other specialties' intervention, such as the speechlanguage pathologist (Ramos et al., 2000). The open bite is a lack of vertical contact between the upper and the lower teeth, and this opening may present different sizes, varying from patient to patient. This anomaly may be considered as a deviation of the vertical relationship of the maxillary and mandibular arches (Monguilhott et al., 2003).

When the vertical cephalometric analysis does not reveal abnormal measures and the problem is restrict to some teeth failure in finding the occlusion line, the condition receives the denomination of simple open bite. But, when the analysis demonstrates a disharmony in the skeletal components of the anterior facial height (example: too short upper facial height or total anterior facial height disproportionally shorter than the total posterior facial height), the dentoalveolar vertical development does not match the desired skeletal morphological pattern. In a simple open bite the alveolar adaptation can't or doesn't take place; in the complex open bite the alveolar adaptation takes place but cannot be maintained (Proffit, 2002).

An open bite is more frequently seen in the anterior region, mainly due to deleterious habits such as digital sucking. In these cases, the open bite is usually assystematic. The teeth position and the alveolar process deformation present a configuration that approximately represents a negative impression of the thumb or other fingers used during the sucking (Proffit, 2002).

Furthermore, an anterior open bite may also be caused by the continuous positioning of the anterior portion of the tongue on the incisal edges of the lower incisors and on the lingual surface of the upper incisors. When the tongue is positioned between the incisal edges of the lower and upper incisors the open bite may be so large that the incisors do not present vertical trespass when the posterior teeth are occluded (Proffit, 2002). The anterior open bites caused exclusively by a habitual tongue protrusion are generally symmetric, contrasting to those caused mainly by a deleterious habit. When the anterior tongue protrusion disappears, the open bite will correct itself spontaneously.

Patients with open bite may present: lack of contact between teeth, deficient labial contact, oral breathing, atypical phonation, maxillary arch constriction, inflamed gums (this characteristic may be localized), increase of the lower $1 / 3$ of the face, open mandibular branch, inclined mandibular plan, long clinical crowns, thin and long symphysis, increased occlusal plan, small mandibular body, maxillary retraction, and tendency to become an Angle's Class II (Freitas, et al, 2003; Monguilhott et al., 2003). The cephalometric evaluation shows a divergence of the horizontal planes (sela-nasion, palatal plan and mandibular plan), with a very elevated angle of the mandibular planes. The occlusal elevation reveals arches with reasonable alignment and possible protrusion of the incisors. The shape of the arch is usually satisfactory, with a possible constriction of the upper arch in a "V" shape. The inter-arcades relation in open bite cases may present two distinct patterns: the divergent occlusal pattern (in total open bites) and the upper occlusal plan with an exaggerated Spee curve (in the anterior open bites) (Monguilhott et al., 2003).

Concerning the speech, the open bite affects the production of the phonemes /t/, /d/, /n/, /l/, /r/ (Ferraz, 2001).

The early treatment of the open bite will provide better functional and skeletal conditions (Lima et al., 2002; Freitas et al., 2003). It may be done during the deciduous, mixed or permanent dentition (Monguilhott, et al., 2003; Stahl \& Gabowsky, 2003). However, from the speech- 
language and orthodontic point of view this anomaly treatment should be early in order to prevent severe bone disharmony and to avoid surgical interventions of great complexity.

The early treatment, many times, solves these anomalies without the necessity of orthodontic treatment. In cases where this isn't enough, once the malocclusion is already established, the orthopedic treatment associated to the speechlanguage treatment is performed (Barreto et al, 2003; Freitas et al., 2003).

The aim of this study was to gather evidences to contribute for a better understanding of the etiology and development of the anterior open bite and its potential association to myofunctional disorders in the studied sample.

\section{Method}

This research was approved by the Research Ethics Committee of the Federal University of Juiz de Fora's Hospital under the protocol n ${ }^{\circ}$ 188-027/ 2002 - Group III.

This study gathered information related to children enrolled in the basic cycle grades of the primary School Fernão Dias Paes located in Juiz de Fora city, in order to verify the possible existing association between harmful oral habits and open bite, as well as the orofacial functions disorders. The exclusion criterion was the attendance to orthodontic treatment and absence of antero-upper elements due to trauma or physiologic conditions. (change of teeth).

The research was conducted in two stages in which firstly the mothers (and/or carer) of children attending the school received a questionnaire elaborated by the authors that should be returned together with the signed Informed Consent Term. The questionnaire comprised questions about milk feeding pattern (natural and/or artificial), respiratory aspects, previous treatments and nonnutritive sucking habits (pacifier use, type of beak used, digital sucking) taking into account the frequency, duration and intensity of the habits. The second stage of the study was performed only with the authorized children and those whose questionnaires were returned. Therefore, a series of clinical, odontologic ( $2^{\mathrm{a}}$ author ICGL) and speech-language exams ( $1^{\mathrm{a}}$ author, CTVM) were performed in 130 children, considering all recommended bio-safety norms. The patient sat in front of the examiner under natural light.

In the odontologic exam, the occlusal conditions such as dentition stage, Angle's classification and malocclusion patterns (open bite, crossbite) were evaluated according to Moyers (1991).

The speech-language exam was composed by the evaluation of facial typology, tongue's habitual position, breathing, swallowing and speech.

The type of face was evaluated according to Enlow's (1993) classification: children with narrow, long and protrusive faces were considered dolichocephalic; children with broader, flatter and less protrusive faces were considered brachycephalic; and children who presented an intermediary type of face, between the dolichocephalic and the brachycephalic, were considered mesocephalic.

The respiratory function was evaluated according to Junqueira (1998), considering the body posture, the lips and jaw posture, the sitting manner, besides the existence of any sealing point of the oral cavity and the maintenance of open lips in relaxed situations. The Glatzel mirror was also used according to Junqueira (1998), for observing the nasal breathing capacity and the symmetry of this function in the nostrils. The child was asked not to modify his/her breathing way when the mirror was placed, and to keep it for some seconds in order to confirm the results. This test was reapplied after the child blew physiologically the nose.

In the evaluation of the habitual tongue position, the posture and the projection of the tongue were observed. When it was not positioned in the upper papilla, it was analyzed if there was some anatomic factor obstructing the adequate position, for example short tongue frenum and narrow palate. In order not to make mistakes in the evaluation, the child was asked to show the location the tongue occupied inside the oral cavity (Junqueira, 1998).

The swallowing exam was performed with water and french bread, observing without touching the child, a possible tongue protrusion and the perioral muscles participation, such as lips and mentalis muscle contraction. In order not to cause a lack of balance in the swallowing process, covering a type of swallowing that is not real, the lips were not opened in the first phase of swallowing, since when they are separated the pressure of the oral cavity is altered causing a lack of balance in the swallowing process (Junqueira, 1998). However, when signs and symptoms of swallowing irregularities were observed, lips were smoothly separated using a tongue lower in order to obtain a confirmed visualization of the interposition (Moyers, 1991). Also, the articulation of phonemes, 
more specifically the presence of distortions, was evaluated according to Junqueira (1998) through spontaneous and directed speech in which the child repeated words when asked to.

For this study a convenience sample was chosen, stressing that the aim is not to generalize data but to describe characteristics of the studied group. The evaluated sample was composed by 130 children, 62 male and 68 female. The data were analyzed through EPI INFO 2000 and SPSS 10, obtaining descriptive results and graphic representations, besides the association measures. The association magnitude was expressed by the relative risk (RR), that indicates the mathematical comparison between the risk of getting ill in a group exposed to any factor and the corresponding risk in a group that is not exposed to the same factor. The fraction or attributable risk was also analyzed which evaluates how much of the phenomenon incidence in the population can actually be delegated to the effect of the supposed risk factor (Patsopoulos et al., 2005). The confidence level adopted was $95 \%$, admitting an error of $5 \%$. The Chi-square test was used to evaluate the association, and the extracts comparison that function as an indicator of the presence of interaction, was evaluated by the Woolf test, a variant of the Chi-square test.

\section{Results}

The mean age of the sample was 9,6 years, ranging from 8 to 12 years old, with no differences between the genders $(p<0,08)$.

As regards to the harmful habits analysis, the pacifier use was the most prevalent habit affecting $76,2 \%$ of the sample, followed by the bottle use, since $62 \%$ of the sample was exclusively fed artificially during an average time of 41 months ( 3 years and 5 months). The digital sucking was found in $12,3 \%$ of the cases and $47,4 \%$ of this total presented it frequently; among those who had already stopped the habit, the mean age of quitting was 80,1 months. Among the children with this habit, 6,3\% slept with the finger in the mouth, as shows Graph 1.

Concerning the respiratory aspects, the presence of pathologies was investigated. According to the carer's information it was observed $35,4 \%$ of positive reports. Among the most commonly cited ones were $52,2 \%$ cases of allergic rhinitis, $34,8 \%$ cases of bronchitis, $4,3 \%$ cases of asthma and $8,7 \%$ of other conditions. According to the carer, $6,2 \%$ of the sample presented pharyngeal and palatal tonsils problems.
According to the Angle's classification of malocclusions, $63,6 \%$ of the children were diagnosed as Class I, 15,5\% as Class II and 3,9\% as Class III. The $17,1 \%$ left presented permanent first molar in an edge to edge occlusion.

The main malocclusions identified in the sample were anterior open bite with trespass, anterior open bite without trespass, exaggerated overbite, bilateral crossbite, anterior crossbite, posterior left crossbite, posterior right crossbite $(33,8 \%, 11,5 \%, 7,7 \%, 3,8 \%$, $2,3 \%, 2,3 \%$ e $0,8 \%$ respectively), as shows Graph 2 .

As regards to the facial type, it was verified that $20 \%$ of the children had a brachycephalic facial type, $66,2 \%$ a mesocephalic type and $13,8 \%$ a dolichocephalic type with no association with the respiratory pattern $(\mathrm{p}<0,06)$.

Concerning the respiratory function of the children, it was observed that $77 \%$ presented nasal breathing, followed by $20 \%$ with oronasal breathing and $3 \%$ with oral breathing, illustrated in Graph 3.

GRAPH 1. Relative frequency of harmful habits and their expression in the sample, schoolchildren from 8 to 12 years old, Juiz de Fora, MG, 2002.

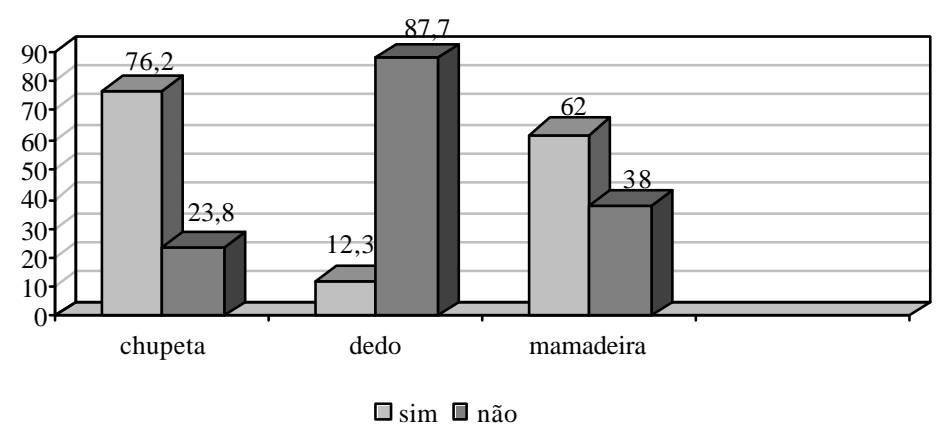

GRAPH 2. Main malocclusions identified, schoolchildren from 8 to 12 years old, Juiz de Fora, MG, 2002.

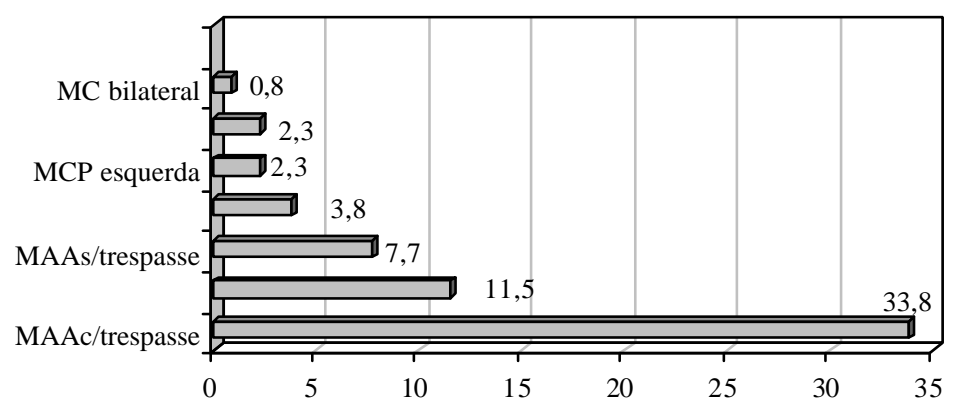

Legenda: $\mathrm{MC}$ bilateral $=$ mordida cruzada bilateral; $\mathrm{MCP}$ esquerda $=$ mordida cruzada posterior esquerda; MAAs/trespasse = mordida aberta anterior sem trespasse; MAAc/trespasse $=$ mordida aberta anterior com trespasse. 
Concerning the habitual tongue position, $22 \%$ of the children presented tongue interposition between the incisors, while $52 \%$ presented tongue interposition during swallowing. Lips contraction was found in $29 \%$ of the subjects while $32 \%$ presented contraction of the mentalis muscle (Graph 4). Figure 1 shows one of the examined children with an open bite performing the mentalis contraction during a labial sealing attempt.

The association between the bottle use and the tongue interposition during swallowing was evaluated (RR 1,92; 1,14-4,35), but the interposition at rest or the articulation disorders were not. The variable duration of the digital and pacifier sucking habit did not influence statistically the function disorder. The anterior open bite with trespass (Figure 2) was statistically associated to the Angle's Class II (p-valor 0,01). However, the anterior open bite without trespass (Figure 3) did not follow this tendency (p-valor 0,08 ). As regard to the facial pattern, the dolichocephalic faces increased the risk for anterior open bite without trespass (RR 3,12; 1,20-9,90), but not for anterior open bite with trespass (RR 1,04; 0,22-5,00).

Chart I shows the association measures between the sucking habits and myofunctional disorders. Analyzing the association between the anterior open bite, the tongue interposition during swallowing and speech articulation disorders, it was observed a significant association between this malocclusion and the tongue interposition with an association measure of 2,44 (TI 1.13-5.27), and the fraction attributed to the tongue interposition by the open bite was $59 \%$. The same was not verified for the phonoarticulatory disorders ( $\mathrm{RR}=$ 0.80; TI 0.20-2.30).

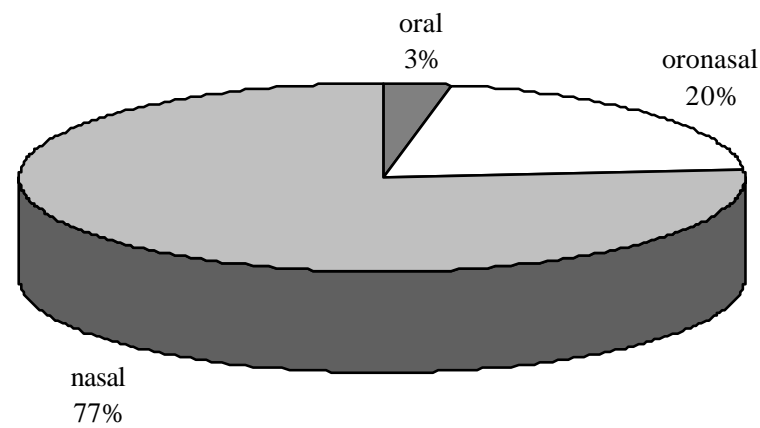


FIGURE 1. Patient with open bite contracting the mentalis muscle during labial sealing.
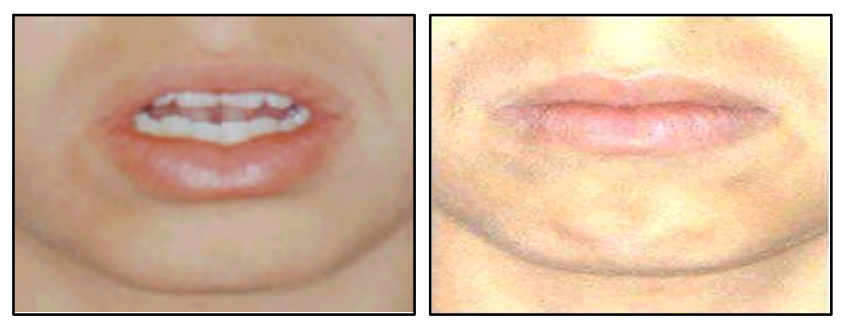

GRAPH 4. Orofacial myofunctional aspects, schoolchildren from 8 to 12 years old, Juiz de Fora, MG, 2002.

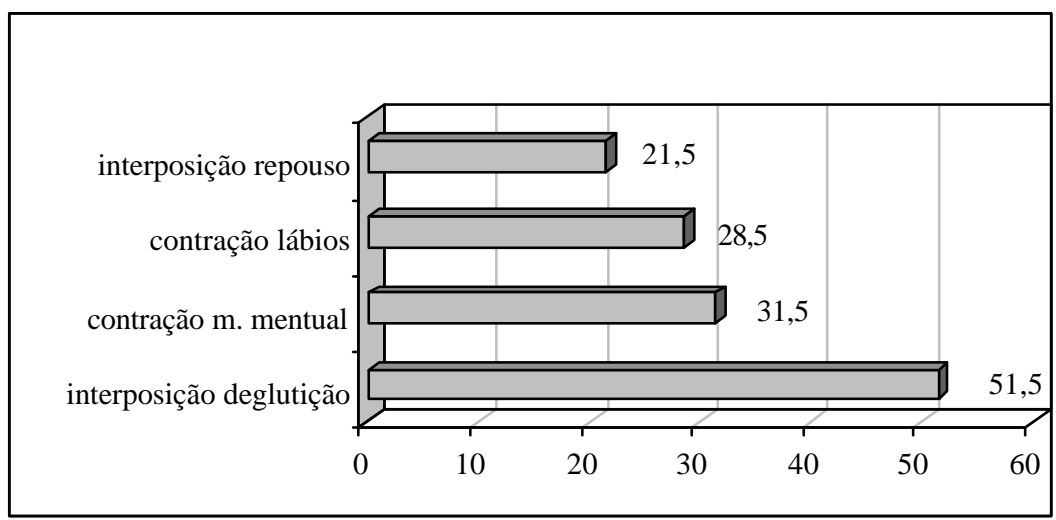

FIGURE 2. Child with anterior open bite with trespass and molar relation Class I.

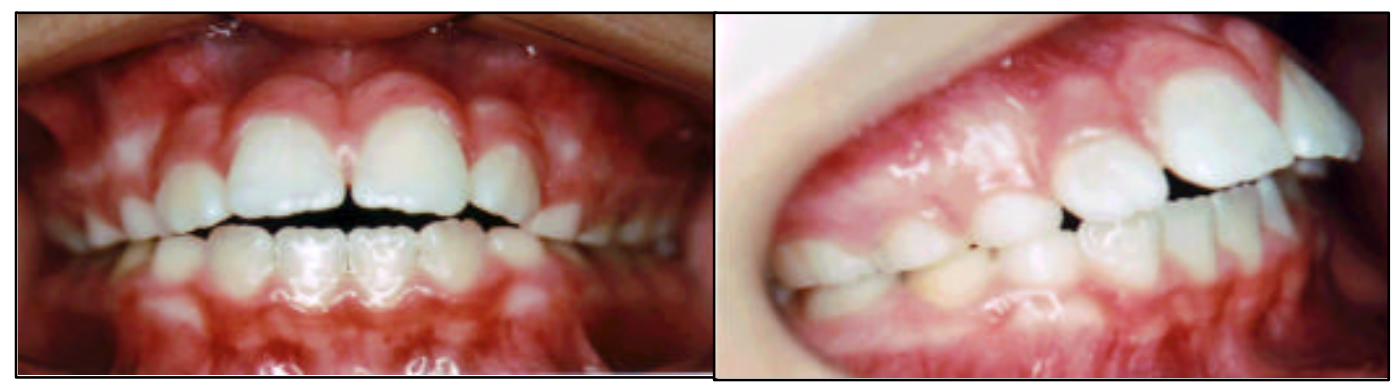

FIGURE 3. Child with anterior open bite with trespass and molar relation Class I.

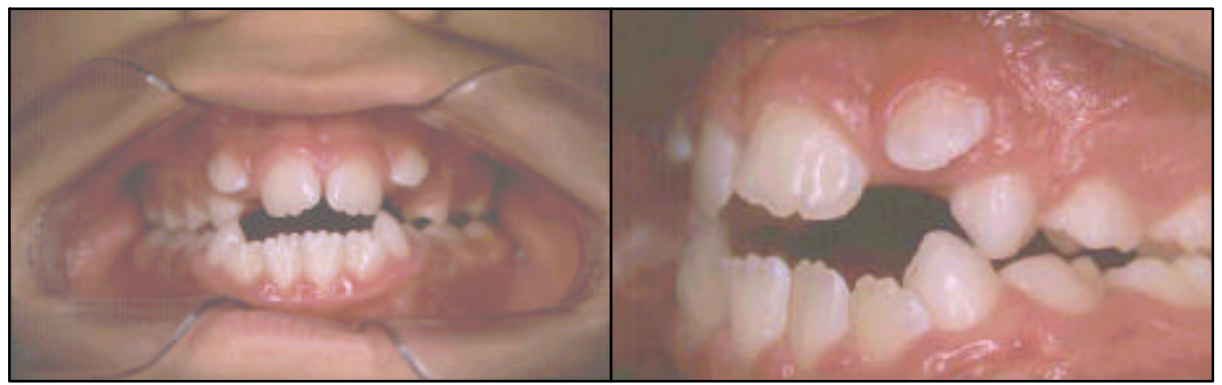


CHART 1. Association measures between non-nutritive sucking habits and orofacial functions.

\begin{tabular}{|c|c|c|c|c|c|}
\hline Hábito / Função & $\begin{array}{c}\text { Posição Habitual da } \\
\text { Língua }\end{array}$ & $\begin{array}{c}\text { Interposição Lingual em } \\
\text { Deglutição }\end{array}$ & Contração de Lábio & Contração de Mento & $\begin{array}{c}\text { Deficiência } \\
\text { Fonoarticulatória }\end{array}$ \\
\hline & RR (IC 95\%) & RR (IC 95\%) & RR (IC 95\%) & RR (IC 95\%) & RR (IC 95\%) \\
\hline sucção digital & $1,24(0,38-4,06)$ & $1,80(1,48-6,46)$ & $2,93(1,89-9,72)$ & $2,17(0,52-10,0)$ & $4,66(1,24-7,43)$ \\
\hline uso de chupeta & $1,69(0,68-4,17)$ & $2,16(1,62-8,20)$ & $1,53(0,91-1,88)$ & $1,44(0,53-3,97)$ & $3,01(1,60-12,36)$ \\
\hline
\end{tabular}

Legenda: $\mathrm{RR}=$ risco relativo; $\mathrm{IC}=$ entervalo de confiança.

\section{Discussion}

Knowing aspects of milk feeding, breathing, facial morphology, non-nutritive sucking habits, as well as dentition stage is of great importance for the speech-language pathologist and the professional of correlated areas, once the early intervention is crucial for the child to perform the functions of chewing, swallowing, breathing and speech, which interfere directly (cause and consequence) on the occlusion.

In this study, the information of several authors was confirmed, once the lips contraction pattern during swallowing seemed to be connected to the digital sucking and to the pacifier use - habits that establish a causal association with the anterior open bite pattern in several literature studies (Penteado, 1995; Cauassani et al., 2003). Equally, Yamaguchi and Sueishi (2003) described that patients with anterior open bite present altered labial tonus and contraction of the peri-orbicular muscle, a factor that may aggravate the malocclusion.

Lima et al. (2002) reported that the vertical growth deficiency in the anterior region of the maxilla, the tongue interposition and the digital sucking habit acting altogether would be the main cause for the installation of an anterior open bite. However, attention should be drawn either to the multiplicity of the open bite's etiology, as to the myofunctional disorders related to speech and swallowing. The habits act over different predetermined genetic growth patterns with different intensity, frequency and duration. This provokes distinct skeletal disorders and diverse muscle responses in different individuals.

Great part of the child population presents the non-nutritive habit of sucking that, if prolonged, may lead to an anterior open bite, although the literature admits that habits during the deciduous dentition have little or no effect on teeth. However, the persistence of the habits during mixed dentition may cause an open bite (Proffit, 2002; Buford \& Noar, 2003). Children examined in this study were in the stage of mixed dentition and great part of them used a pacifier until the age of 4 years or latter. This shows that these habits may have interfered on the labial contraction patterns and on the tongue interposition in an attempt to obtain a palliative action concerning their effect on the alveolar process and on the teeth.

Junqueira (2000) affirms that digital sucking may alter all oral structures, since during sucking a pressure is made against the palate, the upper teeth arch is projected forward and the lower one, backward; additionally, the tongue is positioned on the floor of the lower arch and the lips remain exaggerated open and with eversion.

The individuals with anterior open bite place their tongue between the anterior teeth when they swallow, while those with a normal relation of the incisors don't project it. Therefore, the statistical correlation between the habits and the tongue interposition, at rest or during the function, can be explained in the present study. A study described by Fujiki et al. (2004) corroborates these findings.

Kuramae et al. (2001) called the attention to the fact that swallowing with tongue interposition is the direct result of inappropriate artificial feeding. The findings of the above author were confirmed by this research, until certain point, once it was verified that the bottle use was associated only to the tongue interposition during swallowing, but not to the tongue interposition at rest.

The swallowing alteration associated to the open bite may come from two situations: as a habit in order to reduce the functional opening in the anterior region of the alveolus; or as a result of the skeletal accommodations, in cases of skeletal open bites. On the other hand, the malocclusion caused or not by a harmful habit, although strongly related to it, will determine the tongue positioning pattern. 
According to this position, Proffit (2002) described the swallowing with tongue thrust as being a useful adaptation when an open bite or an overjet are detected. According to the author's evaluation almost all individuals with an open bite present tongue interposition, but the reciprocal may not be true. After the removal of the sucking habit, the bite tends to spontaneously close (in early stages of mixed dentition), although the tongue positioning between the anterior teeth persists.

In the present study, a strong statistical significance between the patients with anterior open bite without trespass and with dolichocephalic, longer faces and with a vertical growth pattern was demonstrated. This result corroborates the findings of Stahl and Gabowsky (2003), who found a vertical maxilla excess in the dentoalveolar region and an increased gonium angle in patients with long faces who presented anterior open bite. It can be complemented that the long faces provide a fertile soil for the pernicious action of oral habits and for the determination of dentoalveolar vertical discrepancies. Only a small portion of the sample of patients had an oral respiratory pattern (3\%) and the oronasal breathing was quite frequent (20\% of the sample). The oral breathing, many times, may cause an excessive horizontal growth of the maxilla, favoring the installation of a Class II malocclusion. Faria et al. (2002) analyzed the respiratory functions of patients with different types of swallowing patterns and stated that children with higher incidence of atypical swallowing were exactly the oral breathers and with an open bite.

The findings of the present study agreed with Zardetto et al. (2002) who verified a relation between the Class II malocclusions and the tendency for open bite. The evaluated children who presented anterior open bite with trespass tended to present a molar relation Class II, and those who presented an open bite without trespass did not. A possible explanation for this would be the fact that the muscles action stimulate and direct the maxilla growth in an antero-posterior direction. With such displacement, the molar relation Class II is established. Fujiki et al. (2004) suggested that the anterior position of the tongue and the jaw's horary rotation (both due to palatal and/or pharyngeal tonsils hypertrophy) may result in an anterior open bite.

Marchesan (1998) stresses that when the child starts to breathe orally, the tongue positions itself differently in the oral cavity for the palatal tonsils and oropharynx protection, and no more plays a role of dental arches shaper. With this, the tongue will stimulate the anterior maxillary growth, leading to a Class II also inhibiting the mandibular growth. Furthermore, it may be projected inter-arches, keeping them apart and causing an anterior open bite.

According to Moyers (1991), the Class II cases with great overjet and overbite are always associated to a labial interposition during swallowing. In these cases the lower lip hyperactivity provides the oral cavity sealing with the lingual faces of the upper incisors. For Marchesan (1998), the impossibility of the upper and lower lips to touch each other generates the altered swallowing pattern. This case is only a functional adaptation of the peri-oral muscles to the malocclusion. It can be noted, therefore, the lips orbicular muscle contraction and specially, the mentalis contraction. When the malocclusion is corrected, the problem will stop. The relationship between the harmful habits or non-nutritive oral habits and the altered muscle function reported in this research shows that there is an association in this sample; nevertheless, it is due to a muscle functional adaptation because of the malocclusion that might or might not have been caused by the harmful habit. A differential diagnosis should be done when the problem persists after the malocclusion correction. According to Marchesan (1998), in this case the mentalis muscle contraction is maintained without the necessity of the anterior sealing.

A predictable result corroborated by this study was the existing relationship between the digital sucking habits and the pacifier use with the atypical swallowing. Junqueira (2000) reports that these habits may force the tongue to stay in the transition between the gingival margin and the teeth, deforming the dental arch, altering the child's speech and yet, becoming a support or a refuge in emotional frustration situations. This swallowing pattern is so important in the malocclusion development that Zardetto et al. (2002) suggested the removal of the habit in first place, before the patient's reeducation as regards to the swallowing pattern.

The malocclusions play a decisive role in the articulation of words, once the tongue position is also determined by the skeletal pattern. In a Class III the tongue tends to position itself under the occlusion plan. In a Class II it is positioned anteriorly. This protruded posture of the tongue may result, according to Moyers (1991), in an open bite, which for Proffit (2002) would be only a result 
of this bite pattern. According to the first author, the dolichocephalic faces with tongue projection are strong candidates for presenting an anterior open bite. The relation between the tongue posture, the phonemes articulation with the digital and/or pacifier sucking habit verified in this study, also seems to be indirect, that is, almost always there is a malocclusion determining the tongue position.

Felício (1999) affirms that the anterior open bite is associated to speech defects that practically affect the fricative phonemes, besides the $/ \mathrm{r} /, / 1 /$, / t/, /d/. Certain phonemes, such as /s/, /t/, /d/, and even $/ 1 /$ are produced by the interdentalization of

\section{Conclusion}

In the present study, the main results were the history of pacifier use $(76,3 \%)$ and the artificial milk feeding $(62 \%)$ presented by the sample. As the main malocclusion pattern identified, there is the anterior open bite with trespass $(33,6 \%$ of the sample). An association between the history of para-functional habits and the occurrence of tongue interposition during swallowing and the articulation disorder was identified.

From this study it was realized the importance of the association of orthodontists / maxillary functional orthopedists and speech-language therapists, since the function of orthodontic braces is limited, that is, it only alters the dental arches disposition, while the speech-language therapy will the tongue, which is not correct and is associated to a similar swallowing pattern, that is, with a tongue interposition. In the analyzed sample, the open bite played a role of risk factor for tongue interposition and consequent alteration in the articulation point of the words.

It's worth it to stress that some results of this study may have been influenced by the sample size, specially providing broad trust intervals or association measures that did not reach statistical significance, such as in the case of association involving open bite without trespass. rehabilitate through oro-myofunctional therapy and emphasize the correct tongue position during swallowing, speech or at rest.

The therapeutic successes will also depend on the conjunct actuation of otorhinolaryngologist and allergist once a number of secondary effects are established as a function of some disorder in the respiratory process. Therefore, the early intervention of the upper airways is fundamental, eliminating the respiratory obstruction and consequently allowing this function rehabilitation.

As a result, it's essential an integral view of the patient and the multidisciplinary team interaction for reaching a significant, integral and efficient rehabilitation. 


\section{References}

BARRETO, E. P. R.; FARIA, M. M. G.; CASTRO, P. R. S. Hábitos bucais de sucção não nutritiva, dedo e chupeta: abordagem multidisciplinar. Jornal Brasileiro de Fonoaudiologia, Curitiba, v. 4., n. 16, p. 06-12, jul.-set. 2003.

BUFORD, D.; NOAR, J. H. The causes, diagnosis and treatment of anterior open bite. Dent. Update, Guilford, v. 30, n. 5, p. 235-340, jun. 2003.

CAUASSANI, V. G. S.; RIBEIRO, S. G.; NEMR, N. K.; GRECO, A. M.; KÖELE, J.; LEHN, C. N. Hábitos orais de sucção: estudo piloto em população de baixa renda. Rev. Bras. Otorrinolaringol., Porto Alegre, v. 69, n. 1, p. 106-110, jan.-fev. 2003.

CIRELli, C. C.; MARTINS, L. P.; MELO, A. C. M.; PAULIN, R. F. Mordida aberta anterior associada a hábitos de succção de chupeta - relato de caso clinico. Jornal Brasileiro de Fonoaudiologia, Curitiba, v. 2, n. 2, p. 36-39, jan.-mar. 2001.

ENLOW, D. H. Crescimento facial. 3. ed. São Paulo: Artes Médicas, 1993. cap. 1, p. 6-11.

FARIA, P. T. M.; RUELLAS, A. C. O.; MATSUMOTO, M. A. N. Dentofacial morphology of mouth breathing children. Braz Dent. J., Ribeirão Preto, v. 13, n. 2, p. 129- 132, maio-ago. 2002.

FELÍCIO, C. M. A. Fonoaudiologia aplicada a casos odontológicos: motricidade oral e audiologia. São Paulo: Pancast, 1999. cap. 2, p. 59- 61.

FREITAS, M. R.; BELTRÃO, R. T. S.; FREITAS, K. M. S.; VILAS-BOAS, J. H. Um tratamento simplicado para a correção da má oclusão classe II, divisão 1, com mordida aberta: relato de um caso clínico. Rev. Dent. Press. Ortodon. Ortopedi Facial, Maringá, v. 8, n. 3, p. 93-100, maio-jun. 2003.

FERRAZ, M. C. Manual prático de motricidade oral: avaliação e tratamento. 5. ed. Rio de Janeiro: Revinter, 2001. p. 26.

FUJIKI, T.; INOUE, M.; MIYAWAKI, S.; NAGASCKI, T.; TANIMOTO, K.; TAKAMO, Y. T. Relationship between maxillofacial morphology and deglutitive tongue movement in patients with anterior open bite. Am. J. Orthod. Dentofacial Orthop., St. Louis, v. 152, n. 2, p. 160-167, feb. 2004.

JUNQUEIRA, P. Avaliação miofuncional. In MARCHESAN, I. Q. Fundamentos em Fonoaudiologia: aspectos clínicos da motricidade oral. Rio de Janeiro: Guanabara Koogan, 1998. cap. 3, p. 13- 21.

JUNQUEIRA, P. Amamentação, hábitos orais e mastigação: orientações, cuidados e dicas. 2 ed. Rio de Janeiro: Revinter, 2000. p. 14- 26.
KURAMAE, M.; TAVARES, S. W.; ALMEIDA, H. A.; ALMEIDA, M. H. C.; NÖUER, D. F. Correção da deglutição atípica associada à mordida aberta anterior: relato de caso clínico. J. Bras. Ortodont. Ortop. Facial, Curitiba, v. 6, n. 36, p. 493-501, dez. 2001.

LIMA, N. J.; PINTO, E. M.; GONDIM, P. P. C. Alterações verticais na dentadura mista: diagnóstico e tratamento. $J$. Bras. Ortodon. Ortop. Facial, Curitiba v. 7, n. 42, p. 511-117, nov.-dez. 2002.

MARCHESAN, I. Q. Fundamentos em Fonoaudiologia: aspectos clínicos da motricidade oral. Rio de Janeiro: Guanabara Koogan, 1998. cap. 6, p. 151-158.

MONGUILHOTT, L. M. T.; FRAZZON, J. S.; CHEREM, V. B. Hábitos de sucção: como e quando tratar na ótica da ortodontia x fonoaudiologia. Rev. Dent. Press. Ortodon. Ortopedi Facial, Maringá, v. 8, n. 1, p. 95-104, jan.-feb. 2003.

MOYERS, R. Ortodontia. 4. ed. Rio de Janeiro: Guanabara Koogan, 1991. p. 175- 467.

PATSOPOULOS N. A.; ANALATOS, A. A.; IONNIDES, S. P., Relative citation impact of various study designs in the health sciences. JAMA, Chicago, v. 293, n. 19 , p. 2362-2366, 2005.

PENTEADO, R. Z.; ALMEIDA, V. F.; LEITE, É. F. D. Saúde bucal em pré-escolares: estudo fonoaudiológico e odontológico, Pró-Fono Revista de Atualização Científica, Barueri, v. 7, n. 2, p. 21-29, set. 1995

PROFFIT, W. R. Ortodontia contemporânea. 3 ed. Rio de Janeiro: Guanabara Koogan, 2002. cap. 5, p. 105-137.

RAMOS, J. M. L.; REIS, M. C. S.; SERRA-NEGRA, J. M. C. Como eliminar os hábitos de sucção não nutritiva? Jornal Brasileiro de Fonoaudiologia, Curitiba, v. 1, n. 3, p. 21-27, abr.-jun. 2000.

SIQUEIRA, V. C. V.; NEGREIROS, P. E.; BENITES, W. R C. A etiologia da mordida aberta na dentadura decídua. Oral Health, Porto Alegre, v. 50, n. 2, p. 99-104, abr.-jun. 2002.

STAHL, F.; GABOWSKY, F. Orthodontic findings in the deciduous and early mixed dentition - inferences for a preventive strategy. J. Orofacial Orthop., Munique, v. 64, n. 6, p. 401-406, nov. 2003.

YAMAGUCHI, H.; SUEISHI, K L. Malocclusion associated with abnormal posture. Bull Tokyo Dent Coll., Tokio, v. 44, n. 2, p. 43-54, may. 2003.

ZARDETTO, C. G.; RODRIGUES, C. R.; STEFANI F. M. Effects of different pacifiers on the primary dentition and oral myofunctional strutures of preeschool children. Pediatr. Dent., Chicago, v. 24, n. 6, p. 552-560, nov.-dec. 2002.

Endereço para correspondência:

Cristina Tostes Vieira Maciel

R. Itamar Soares de Oliveira, 56, apto. 403 - Cascatinha - Juiz de Fora - MG - CEP: 36033-280. 